\title{
LIVING WITH LEUKAEMIA
}

Leukaemias are cancers of the blood or bone marrow. But how do they form, and can they be treated? By Emily Elert.

\section{TYPES OF LEUKAEMIA}

Most leukaemias are either myeloid or lymphocytic/lymphoblastic, depending on which cells they affect, and can be either chronic or acute.

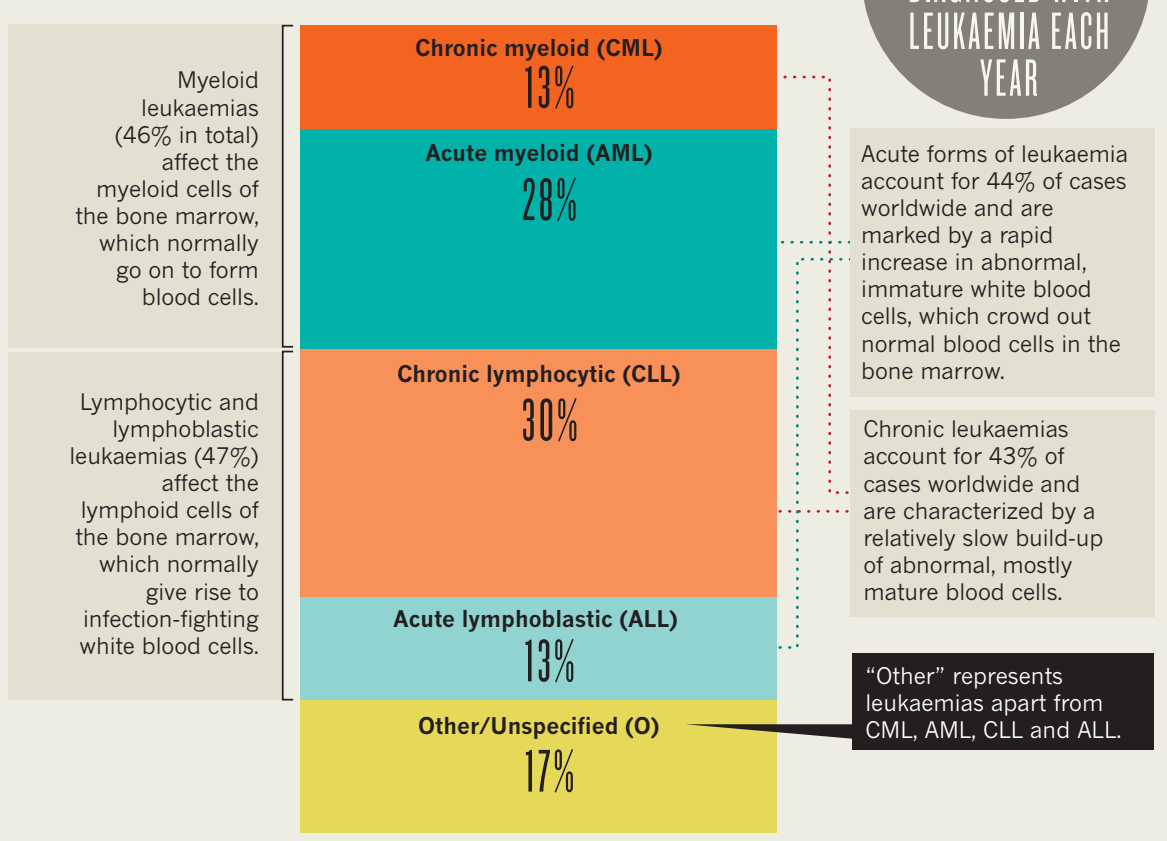

\section{AGE OF ONSET}

Most leukaemia occurs in the elderly, but there is a separate, smaller peak in childhood.

20,000

\begin{tabular}{l|l|lll} 
CML & AML & CLL & ALL & 0
\end{tabular}

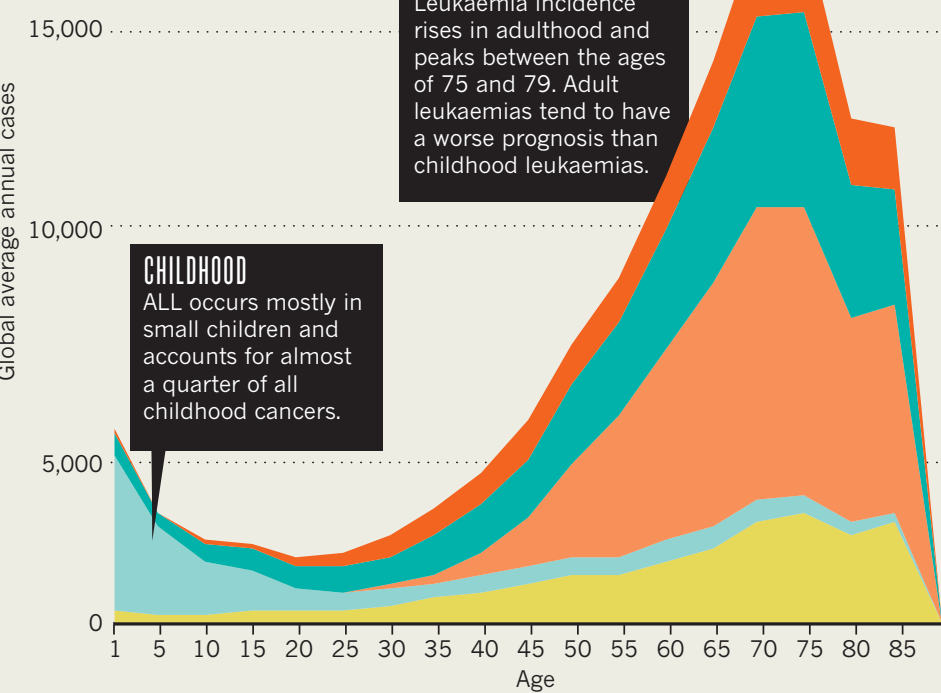

\section{TREATMENT TIMELINE}

Important advances in the treatment of leukaemia.

Aminopterin becomes the first known compound to inhibit the growth of cancer. It is shown to cause temporary remissions

in acute lymphoblastic leukaemia in children.
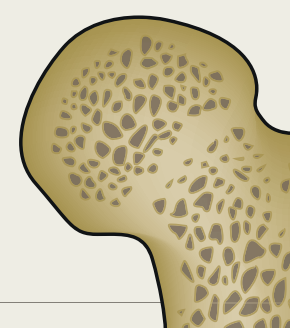


\section{CELL TYPE}

At every step in the differentiation process, the range of fates available to a progenitor cell narrows. Leukaemias can occur at any stage in this process.

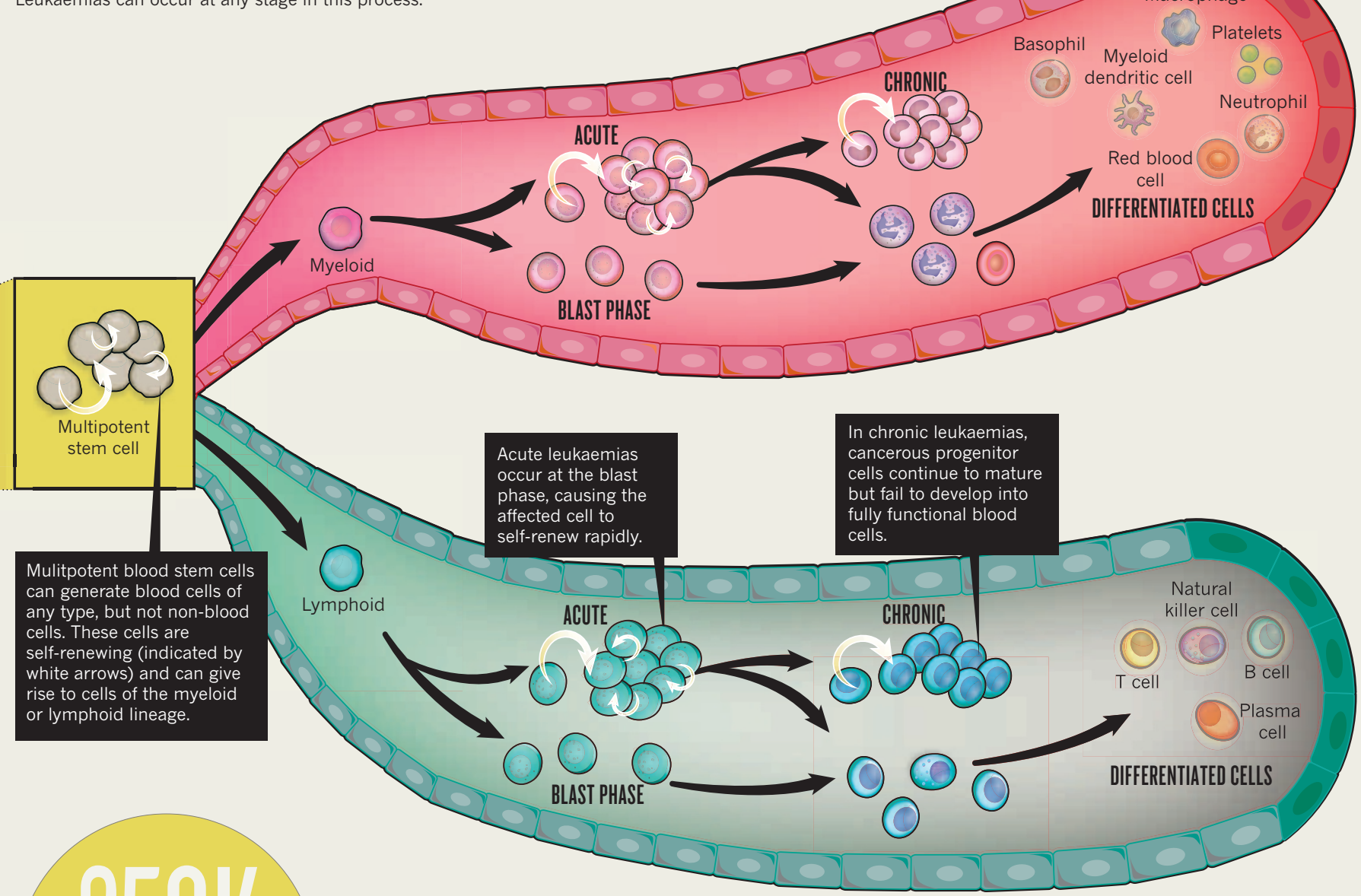

1995

Scientists discover the 'graft-versus-leukaemia' effect: giving leukaemia patients a dose of healthy white blood cells can help their cancer go back into remission.

\begin{tabular}{r||l}
1985 & 1986 \\
A bone- & marrow \\
The National \\
transplant is \\
used to cure \\
leukaemia for & $\begin{array}{l}\text { Marrow Donor } \\
\text { Prom, a US } \\
\text { bone-marrow } \\
\text { transplant } \\
\text { the first time. }\end{array}$ \\
$\begin{array}{l}\text { registry, is } \\
\text { established. }\end{array}$
\end{tabular}

2004

The first epigenetic drug is approved to prevent cancer in patients with myelodysplastic syndrome, which can lead to leukaemia.
Scientists sequence the genome of a patient with acute myeloid leukaemia, paving the way for better targeted therapies.

1980

1990

2000

2010

\section{5-YEAR SURVIVABILITY IN THE UNITED STATES}

The likelihood of surviving with leukaemia for 5 years has been increasing steadily for more than 30 years as treatments have improved.

CLL ALL $\triangle \mathrm{CML} \square \mathrm{AML}$

100

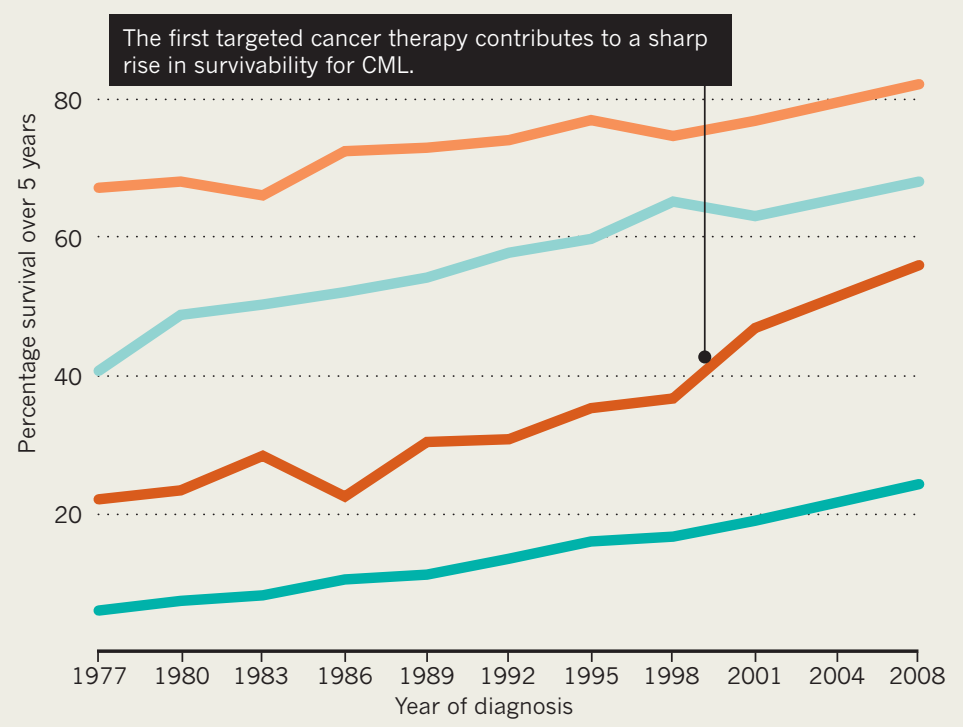

